ISSN: 2302-8556

E-Jurnal Akuntansi Universitas Udayana

Vol.26.2.Februari (2019): 1161-1189

DOI: https://doi.org/10.24843/EJA.2019.v26.i02.p12

\title{
Pengaruh Sifat Machiavellian, Time Budget Pressure, Loc Pada Dysfunctional Audit Behavior, Akuntan Publik Di Bali
}

\author{
A.A Istri Pranyanita ${ }^{1}$ \\ I Ketut Sujana ${ }^{2}$
${ }^{1,2}$ Fakultas Ekonomi dan Bisnis Universitas Udayana (Unud), Bali, Indonesia e-mail: istripranyanita@gmail.com

\begin{abstract}
ABSTRAK
Penelitian ini bertujuan untuk memeroleh bukti empiris mengenai pengaruh sifat machiavellian, time budget pressure, locus of control pada dysfunctional audit behavior. Populasi dalam penelitian ini adalah auditor yang bekerja pada kantor akuntan publik di Bali dengan jumlah sampel sebanyak 54 auditor, yang diambil menggunakan metode purposive sampling. Teknik analisis data yang digunakan dalam penelitian ini adalah analisis regresi linear berganda.Hasil pengujian menunjukkan bahwa sifat machiavellian, time budget pressure, dan locus of control eksternal berpengaruh positif pada dysfunctional audit behavior. Sedangkan locus of control internal berpengaruh negatif pada dysfunctional audit behavior. Salah satu faktor yang memengaruhi penyimpangan perilaku ini adalah faktor internal yaitu karakteristik personal, maupun faktor eksternal yang berada pada lingkungan luar auditor tersebut. Dysfunctional audit behavior dapat menurunkan kualitas audit yang berdampak pada profesi auditing.
\end{abstract}

Kata kunci :Dysfunctional audit behavior, machiavellian, time budget pressure

\begin{abstract}
This study aims to obtain empirical evidence regarding the effect of machiavellian properties, time budget pressure, locus of control on behavioral dysfunctional audit. The population in this study is an auditor who works in a public accounting firm in Bali with a total sample of 54 auditors, taken using a purposive sampling method. The data analysis technique used in this study is multiple linear regression analysis. The test results show that machiavellian properties, time budget pressure, and external locus of control have a positive effect on behavioral dysfunctional audit. Whereas internal locus of control has a negative effect on behavioral dysfunctional audit. One of the factors that influence this behavior deviation is internal factors, namely personal characteristics, as well as external factors that are in the outside environment of the auditor. Dysfunctional audit behavior can reduce audit quality that has an impact on the auditing profession.
\end{abstract}

Keywords: Dysfunctional audit behavior, machiavellian, time budget pressure 


\section{PENDAHULUAN}

Profesi Akuntan Publik merupakan salah satu profesi akuntan yang menjual jasa kepada masyarakat ataupun kliennya, terutama untuk jenis layanan atau jasa pemeriksaan laporan keuangan. Menurut UU Akuntan Publik No. 5 Tahun 2011, Akuntan Publik adalah seseorang yang telah memperoleh izin untuk memberikan jasa sebagaimana diatur dalam Undang-Undang tersebut. Ketentuan mengenai akuntan publik diIndonesia diatur dalam Undang-Undang Republik Indonesia Nomor 5 Tahun 2011 tentang Akuntan Publik dan Peraturan Menteri Keuangan Nomor 17/PMK.01/2008 tentang Jasa Akuntan Publik. Akuntan publik adalah akuntan independen yang memberikan jasa akuntansi tertentu dan menerima pembayaran atas jasa yang telah diberikannya. Dengan demikian, bukan hanya keahlian yang dituntut dari seorang akuntan publik, tetapi juga kejujuran (integritas) dalam melakukan pekerjaan. Hal ini penting karena pihak-pihak yang berkepentingan terhadap laporan keuangan sangat bergantung pada pendapat/opini akuntan publik.

Pertumbuhan bisnis yang meningkat, menyebabkan semakin banyak perusahaan yang membutuhkan jasa audit. Hal ini menimbulkan persaingan jasa audit yang meningkat yang ditandai dengan semakin banyaknya firma audit. Kondisi demikian dapat mengarahkan pada persaingan KAP yang tidak sehat, sehingga dapat menjadikan kantor akuntan mengurangi jam kerja mereka supaya margin yang diperoleh masih berada pada tingkat yang dapat diterima. Perilaku akuntan, maupun akuntan publik akan menentukan hasil pekerjaannya. Masyarakat, khususnya klien yang memakai jasa akuntan publik harus yakin, dalam melaksanakan tugasnya 
ISSN: 2302-8556

E-Jurnal Akuntansi Universitas Udayana

Vol.26.2.Februari (2019): 1161-1189

akuntan tersebut mempunyai prinsip moral yang baik. Sehingga adanya jaminan untuk melindungi kepentingan masyarakat dari praktik-praktik yang tidak benar. Akuntan publik sebagai profesi yang memberikan jasa assurance tentang informasi laporan keuangan historis kepada masyarakat diwajibkan untuk memiliki pengetahuan dan keterampilan akuntansi serta kualitas pribadi yang memadai. Kualitas pribadi tersebut akan tercermin dari perilaku profesinya. Salah satu sikap professional akuntan publik ditunjukan dengan menghindari penyimpangan perilaku dalam audit. Perilaku disfungsional yang dimaksud di sini adalah perilaku auditor yang menyimpang dari standar auditing dalam melaksanakan penugasan audit yang dapat menurunkan kualitas hasil audit. Perilaku disfungsional seperti premature signoff, pengumpulan bukti audit yang tidak memadai, penghilangan atau penggantian prosedur audit, dan underreporting of audit time akan menurunkan kualitas audit yang pada akhirnya berdampak negatif terhadap profesi auditing. Menurut Donnelly, Quirin, and O’Bryan 2003 perilaku disfungsional yang umumnya dilakukan oleh auditor diantaranya: (1) underreporting of audit time, (2) premature sign-off, (3) altering/replacing of audit procedure. Dampak negatif dari underreporting of time adalah dapat menciptakan tekanan waktu yang menyebabkan auditor untuk terlibat dalam bentuk langsung dysfunctional audit behavior. Donnelly, et al., (2011)

Beberapa kasus atau fenomena yang terjadi diantaranya: kasus yang menimpa akuntan publik Justinus Aditya Sidharta yang diindikasi melakukan kesalahan dalam mengaudit laporan keuangan PT. Great River Internasional, Tbk. Kasus tersebut muncul setelah adanya temuan auditor investigasi dari BAPEPAM yang menemukan 
indikasi penggelembungan account penjualan, piutang dan asset hingga ratusan milyar rupiah pada laporan keuangan Great River yang mengakibatkan perusahaan tersebut akhirnya kesulitan arus kas dan gagal dalam membayar utang. Sehingga berdasarkan investigasi tersebut BAPEPAM menyatakan bahwa akuntan publik yang memeriksa laporan keuangan Great River ikut menjadi tersangka. Oleh karenanya Menteri Keuangan RI terhitung sejak tanggal 28 November 2006 telah membekukan izin akuntan publik Justinus Aditya Sidharta selama dua tahun karena terbukti melakukan pelanggaran terhadap Standar Profesi Akuntan Publik (SPAP) berkaitan dengan laporan Audit atas Laporan Keuangan Konsolidasi PT. Great River International Tbk (Halman 2017).

Kasus lainnya adalah kasus Kimia Farma yang berawaldari laporan KAP Hans Tuanakotta Mustofa (KAP HTM) kepada BAPEPAM atas penggelembungan penjualan dan aset pada Laporan Keuangan PT Kimia Farma yang telah mereka audit. KAP HTM melakukan pelaporan sebagai bentuk ketaatan atas aturan BAPEPAM. Dalam kenyataannya, ketaatan KAP HTM mendapat hukuman dari Kantor Menteri Negara BUMN. Mereka dilarang untuk mengaudit seluruh Badan Usaha Milik Negara (Halman 2017). Kasus lain yang terjadi yaitu pada salah satu KAP di Bali, dimana Menteri Keuangan (Menkeu) membekukan izin salah satu KAP tersebut selama enam bulan. Pembekuan izin yang tertuang dalam keputusan Nomor 325/KM.1/2007 itu mulai berlaku sejak tanggal 23 Mei 2007. Sanksi pembekuan izin diberikan karena AP tersebut melakukan pelanggaran terhadap Standar Profesional Akuntan Publik (SPAP) dalam pelaksanaan audit atas laporan keuangan Balihai 
ISSN: 2302-8556

E-Jurnal Akuntansi Universitas Udayana

Vol.26.2.Februari (2019): 1161-1189

Resort and Spa untuk tahun buku 2004 yang berpotensi berpengaruh signifikan terhadap Laporan Auditor Independen (www.detik.finance.com).

Tudingan yang menunjuk profesi akuntan menimbulkan pertanyaan besar mengapa auditor bisa terlibat dalam penyimpangan perilaku, dan apakah faktor kepribadian akuntan memiliki pengaruh pada pengambilan keputusan yang tidak etis sehingga menyebabkan terjadinya perilaku disfungsional. Auditor secara individu yang bekerja di bawah nama KAP juga akan mendapatkan dampak tekanan yang dapat berasal dari KAP yang dapat mengarah kepada dysfunctional behavior. (Donnelly et al. 2003) menyatakan bahwa faktor internal individu berpotensi memengaruhi auditor untuk menerima perilaku disfungsional. Hal ini juga sejalan dengan penelitian Paino et al., (2010), yang menyatakan bahwa dysfunctional audit behavior dapat memengaruhi kemampuan KAP dalam memperoleh pendapatan, memenuhi kualitas kerja profesional, dan mengevaluasi kinerja pegawai dengan akurat.

Faktor yang dianggap dapat memengaruhi penyimpangan perilaku audit yaitu, sifat machiavellian dan tipe kepribadian merupakan sifat utama yang dapat memengaruhi perilaku suatu organisasi (Robbins, 2008). Perilaku akuntansi kreatif tampaknya berdampak pada penalaran etika atau untuk melakukan perilaku tidak etis yang lebih lanjut terdiri dari item manipulatif. Perilaku semacam ini dekat dengan machiavellian (Vladu, 2013). Hal ini desebabkan karena sifat machiavellian yang menghalalkan segala cara untuk mencapai tujuan meningkatkan peluang bagi auditor untuk melakukan perilaku disfungsional. Sifat machavellian ialah sifat manipulatif 
A.A. Istri Pranyanita dan I Ketut Sujana. Pengaruh...

yang berdampak negatif bagi profesi akuntan publik, yang menimbulkan krisis kepercayaan masyarakat terhadap opini auditor. Hal tersebut memunculkan pertanyaan apakah auditor sebenarnya menemukan kesalahan pada laporan keuangan namun dengan sengaja memanipulasi hasilnya, atau auditor memang tidak memiliki kemampuan dalam menemukan masalah audit (Ruric 2014). Hasil penelitian Richmond (2003) menunjukkan bahwa kecenderungan seseorang semakin tinggi untuk melakukan tindakan yang tidak etis apabila sifat machiavellian yang dimiliki semakin tinggi. Hasil penelitian tersebut sejalan dengan penelitian (Saputri dan Wirama 2015) menunjukkan bahwa semakin tinggi sifat Machiavellianauditor, maka semakin tinggi pula kecenderungan auditor untuk melakukan perilaku disfungsional. Sejalan dengan penelitian Winanda (2017) yang juga menyatakan bahwa sifat machiavellian berpengaruh positif pada perilaku disfungsional audit.

Time budget pressure dianggap sebagai salah satu faktor yang memengaruhi penyimpangan perilaku audit Margheim, et al., (2005). Tekanan yang dialami auditor dalam melakukan efisiensi waktu pada pekerjaannya memengaruhi perilaku auditor. Pertahanan sikap etis dan profesional berkaitan dengan time budget pressure yang dilakukan oleh para auditor Broberg et al., (2017). Tugas- tugas audit yang tidak realistis dengan anggaran waktu, berdampak pada timbulnya perilaku yang dapat menyebabkan penurunan kualitas audit. Persaingan antar KAP menyebabkan terbatasnya anggaran waktu, dan secara tidak langsung hal ini mendorong auditor untuk melakukan time budget pressure. Tekanan anggaran waktu mengarah pada mendesaknya anggran waktu yang timbul pada saat pelaksanaan tugas yang 
ISSN: 2302-8556

E-Jurnal Akuntansi Universitas Udayana

Vol.26.2.Februari (2019): 1161-1189

disebabkan karena terbatasnya alokasi waktu (DeZoort and Lord, 1997) Hasil penelitian Dewi (2015) menyatakan bahwa time budget pressure berpengaruh positif pada dysfunctional audit behavior. Hal ini sejalan dengan penelitian Winanda (2017) yang menunjukkan tekanan anggaran waktu berpengaruh positif terhadap perilaku disfungsional audit. Namun, penelitian (Devi, 2016) menyatakan bahwa time budget pressure tidak memiliki pengaruh pada penerimaan perilaku disfungsional audit secara langsung.

Faktor lainnya yang dianggap dapat memengaruhi penyimpangan perilaku audit yaitu, locus of control (LOC) atau lokus pengendalian yang merupakan kendali individu atas pekerjaan mereka dan kepercayaan mereka terhadap keberhasilan diri. Seseorang dengan external locus of control merasa dirinya lebih mudah terancam dan cenderung reaktif dalam penyelesaian masalah (Husna, 2012). Seorang auditor dengan external locus ofcontrol lebih dapat terlibat dalam perilaku disfungsional karena perilaku ini dipandang sebagai alat atau cara yang digunakan untuk meraih tujuan Wahyudin et al., (2011). Donnelly et al. (2003) mengemukakan penyebab para auditor melakukan penyimpangan tersebut adalah karakteristik personal yang berupa lokus kendali eksternal (external locus of control), keinginan untuk berhenti kerja (turnover intention) dan tingkat kinerja pribadi karyawan (self rate employee performance) yang dimiliki oleh para auditor. Hasil penelitian mereka menyatakan bahwa terdapat hubungan positif antara locus of control eksternal dengan tingkat penerimaan penyimpangan perilaku dalam audit. Hasil penelitian tersebut sejalan dengan Basudewa and Lely Aryani Merkusiwati (2015) yang menyatakan bahwa 
A.A. Istri Pranyanita dan I Ketut Sujana. Pengaruh...

locus of control berpengaruh positif pada penyimpangan perilaku audit. Sejalan dengan penelitian Dewi (2015) menyatakan bahwa terjadi hubungan positif LOC pada dysfunctional audit behavior.

Sifat machiavellian merupakan sifat yang negatif karena mengabaikan pentingnya integritas dan kejujuran dalam mencapai tujuan. Menurut (Epstein and Sridhar Ramamoorti, 2016) menyatakan bahwa kepribadian machiavellian ditandai oleh manipulasi dan eksploitasi orang lain, ketidaktahuan yang sinis terhadap moralitas, dan fokus pada kepentingan diri sendiri dan penipuan. Individu yang memiliki sifat machiavellian adalah mereka yang memanipulasi orang lain untuk mendapatkan tujuan yang mereka inginkan Triki et al., (2017). (Bass 1999) dalam penelitiannya menjelaskan bahwa Sifat machiavellian yang tinggi dapat berdampak seseorang berperilaku manipulative, persuasive, dan curang dalam meraih tujuan akhir.

Hasil penelitian Richmond (2003) dalam Purnamasari (2006) menunjukkan bahwa kecenderungan seseorang semakin tinggi untuk melakukan tindakan yang tidak etis apabila sifat Machiavellian yang dimiliki semakin tinggi. Hal ini didukung juga oleh penelitian Saputri dan Wirama (2015) yang menyatakan bahwa sifat machiavellian dalam diri auditor menyebabkan auditor lebih rentan melakukan perilaku disfungsional.Sejalan dengan penelitian sebelumnya, pada penelitian Winanda (2017) menyatakan bahwa sifat Machiavellian berpengaruh positif pada perilaku disfungsional auditor. Berdasarkan uraian diatas, maka hipotesis penelitian ini adalah sebagai berikut. 
ISSN: 2302-8556

E-Jurnal Akuntansi Universitas Udayana

Vol.26.2.Februari (2019): 1161-1189

$\mathrm{H}_{1}$ : Sifat Machiavellian berpengaruh positif pada Dysfunctional audit behavior.

Time budget pressure atau tekanan anggaran waktu adalah suatu keadaan yang menunjukkan auditor dituntut untuk melakukan efisiensi terhadap anggaran waktu yang telah disusun atau terdapat pembatasan waktu dalam anggaran yang sangat ketat dan kaku Sososutikso (2010). DeZoort and Lord (1997) dalam Manullang (2010) menyebutkan, ketika menghadapi tekanan anggaran waktu, auditor akan memberikan respon dengan dua cara, yaitu fungsional dan disfungsional. Tingkat tekanan anggaran waktu (time budget pressure) yang tinggi mendorong auditor untuk melakukan perilaku disfungsional (Suprianto 2009).

Penelitian Svanstrom (2016) menunjukkan bahwa tekanan anggaran waktu berpengaruh positif pada perilaku disfungsional di swedia. Penelitian ini sejalan dengan penelitian yang dilakukan oleh Dewi (2015) yang menunjukkan bahwa tekanan anggaran waktu secara langsung berpengaruh positif pada perilaku disfungsional audit. Penelitian Suprianto (2009) menunjukkan bahwa tingkat tekanan anggaran waktu secara langsung berpengaruh positif pada perilaku disfungsional audit. Penelitian serupa juga dilakukan oleh Sososutikso (2010) dimana penelitian ini menunjukkan bahwa tekanan anggaran waktu berpengaruh signifikan pada perilaku disfungsional audit. Jadi, berdasarkan penjabaran penelitian-penelitian terdahulu maka dapat disimpulkan bahwa semakin besar peningkatan tekanan anggaran waktu maka semakin tinggi kecenderungan auditor melakukan suatu perilaku disfungsional. Berdasarkan uraian diatas, maka hipotesis yang diajukan pada penelitian ini adalah $\mathrm{H}_{2}$ : Time budget pressureberpengaruh positif pada dysfunctional audit behavior. 
Locus of control memainkan peranan penting dalam kinerja dalamakuntansi seperti pada anggaran partisipatif. Locus of control individu dalam literatur dibagi menjadi interal dan eksternal, locus of control internal merupakan kontrol atas hidupnya dengan pilihan yang dibuat, dan hasil yang didapatkan terlahir dari upaya individu tersebut. Sebaliknya, locus of control eksternal percaya bahwa takdir individu tersebut dikendalikan oleh orang-orang yang berkuasa, kekuatan yang berasal dari luar kendali, keberuntungan, dan membuat individu tersebut tidak memiliki tanggung jawab pribadi (Domino 2015). Locus of control mengacu pada sejauh mana tingkat kepercayaan seseorang terhadap pengendalian peristiwa yang mampu memengaruhi individu tersebut (Payne and Hysong 2016).

Dalam teori artribusi faktor internal seperti locus of control dapat memengaruhi individu dalam melaksanakan audit. Hal ni dapat terjadi berdasar pada tingkat keyakinan dari masing-masing individu saat menghadapi kejadian dalam melaksanakan tugasnya. Locus of control berperan dalam motivasi, locus of control yang berbeda bisa mencerminkan motivasi yang berbeda dan kinerja yang berbeda. Diduga bahwa semakin tinggi locus of control eksternal individu, semakin besar kemungkinan individu tersebutmenerima perilaku disfungsional. Hal tersebut diperkuat dengan hasil penelitian (Donnelly et al. 2003) yang menyatakan bahwa locus of control internal akan menurunkan dysfunctional audit behavior. Penelitian Shapeero (2003) menyatakan locus of control internal akan berpengaruh negatif pada dysfunctional audit behavior. Sejalan dengan penelitian sebelumnya, penelitian (Irawati, 2005) menyatakan bahwa locus of control menurunkan dysfunctional audit 
ISSN: 2302-8556

E-Jurnal Akuntansi Universitas Udayana

Vol.26.2.Februari (2019): 1161-1189

behavior, atau dapat dikatakan berpengaruh negatif pada dysfunctional audit behavior.

Hasil penelitian (Harini, et. al., 2010) juga membuktikan bahwa locus of control eksternal berpengaruh positif pada perilaku disfungsional audit. Penelitian (Donnelly et al. 2003) yang menunjukkan bahwa semakin tinggi locus of control eksternal seorang auditor, semakin besar kemungkinan terjadinya dysfunctional audit behavior. Gustati (2012) menyatakan locus of control eksternal berpengaruh positif pada penerimaan perilaku disfungsional audit. Secara simultan ditemukan bahwa locus of control internal berpengaruh negatif pada dysfunctional audit behavior dan locus of control eksternal berpengaruh positif pada perilaku disfungsional audit. Berdasarkan uraian tersebut maka hipotesis yang dikembangkan adalah $\mathrm{H}_{3 \mathrm{a}}$ :Locus of control internalberpengaruh negatif pada dysfunctional audit behavior. $\mathrm{H}_{3 \mathrm{~b}}$ :Locus of control eksternal berpengaruh positif pada dysfunctional audit behavior.

\section{METODE PENELITIAN}

Responden dalam penelitian ini adalah auditor pada Kantor Akuntan Publik di Bali yang sudah terdaftar dalam Direktori yang diterbitkan oleh Institut Akuntan Publik Indonesia (IAPI). Kantor Akuntan Publik yang terdaftar pada IAI akan mempermudah pengumpulan data dikarenakan kantor akuntan publik tersebut sudah diketahui nama dan alamatnya serta memiliki izin dari Menteri Keuangan RI sebagai wadah dari akuntan publik dalam melaksanakan pekerjaannya. 
Populasi dalam penelitian ini adalah seluruh auditor yang bekerja pada Kantor Akuntan Publik (KAP) di Bali. Peneliti memilih auditor sebagai populasi karena auditor terjun langsung ke lapangan dalam melakukan pofesi auditnya sehingga lebih rentan terhadap penerimaan perilaku disfungsional auditor dalam melakukan proses audit yang dapat memengaruhi hasil audit. Metode yang digunakan peneliti dalam memilih sampel penelitian adalah pemilihan sampel bertujuan (purposive sampling). Adapun kriteria penentuan sampel dalam penelitan ini adalah auditor yang bekerja pada Kantor Akuntan Publik (KAP) di Bali dan terdaftar di IAPI; Auditor yang mempunyai pengalaman kerja minimal 1 tahun; Auditor yang berstatus aktif dan tidak dibatasi jabatannya baik partner, manajer, auditor senior atau auditor junior.

Tabel 2.

Jumlah Auditor pada Kantor Akuntan Publik di Bali Tahun 2017

\begin{tabular}{llc}
\hline No & \multicolumn{1}{c}{ Nama Kantor Akuntan Publik } & $\begin{array}{c}\text { Jumlah Auditor } \\
\text { (Orang) }\end{array}$ \\
\hline 1. & KAP Arnaya \& Darmayasa & 2 \\
2. & KAP Budhananda Munidewi & 5 \\
3. & KAP I Wayan Ramantha & 7 \\
4. & KAP. K Gunarsa & 12 \\
5. & KAP Drs. Ketut Budiartha, Msi & 10 \\
6. & KAP Drs Ketut Muliartha RM \& Rekan & 7 \\
7. & KAP Drs. Sri Marmo Djogosarkoro \& Rekan & 7 \\
8. & KAP Drs. Wayan Sunasdyana & 6 \\
9. & KAP Johan Malonda Mustika \& Rekan (Cab) & 10 \\
& Total & 77
\end{tabular}

Sumber: Data diolah, 2018

Teknik analisis yang digunakan pada penelitian ini adalah Analisis linear berganda yang berfungsi untuk mengetahui pengaruh variabel independen pada variabel dependen. Persamaan uji regresi linear berganda pada penelitian ini adalah sebagai berikut :

$$
Y=\alpha+\beta_{1} X_{1}+\beta_{2} X_{2}+\beta_{3 a} X_{3 a}+\beta_{3 b} X_{3 b}+e
$$


ISSN: 2302-8556

E-Jurnal Akuntansi Universitas Udayana

Vol.26.2.Februari (2019): 1161-1189

Keterangan :

$\begin{array}{ll}\mathrm{Y} & =\text { dysfunctional audit behavior } \\ \alpha & =\text { konstanta } \\ \beta_{1}, \beta_{2}, \beta_{3 \mathrm{a}}, \beta_{3 \mathrm{~b}} & =\text { koefisien regresi parsial } \\ \mathrm{X}_{1} & =\text { sifat machiavellian } \\ \mathrm{X}_{2} & =\text { time budget pressure } \\ \mathrm{X}_{3 \mathrm{a}} & =\text { locus of control internal } \\ \mathrm{X}_{3 \mathrm{~b}} & =\text { locus of control eksternal } \\ \mathrm{e} & =\text { standar } \text { error }\end{array}$

\section{HASIL DAN PEMBAHASAN}

Statistik deskriptif merupakan gambaran karakteristik dari variabel-variabel yang diteliti yaitu dysfunctional audit behavior, sifat machiavellian, time budget pressure, locus of control terkait dengan jumlah pengamatan, nilai minimum, nilai mean, dan standar deviasi. Hasil Statistik deskriptif disajikan pada tabel 3, sebagai berikut.

Tabel 3. Hasil Statistik Deskriptif

\begin{tabular}{lccccc}
\hline \multicolumn{1}{c}{ Variabel } & N & Min. & Maks. & Mean & Std. Deviasi \\
\hline Dysfunctional audit behavior $(\mathrm{Y})$ & 54 & 23 & 43 & 33,61 & 5,441 \\
Sifat Machiavellian $\left(\mathrm{X}_{1}\right)$ & 54 & 14 & 29 & 23,07 & 4,028 \\
Time budget pressure $\left(\mathrm{X}_{2}\right)$ & 54 & 17 & 32 & 26,41 & 4,105 \\
LOC Internal $\left(\mathrm{X}_{3 \mathrm{a}}\right)$ & 54 & 17 & 33 & 24,07 & 3,855 \\
LOC Eksternal $\left(\mathrm{X}_{3 \mathrm{~b}}\right)$ & 54 & 16 & 31 & 24,65 & 3,640 \\
\hline
\end{tabular}

Sumber:Data diolah, 2018

Berdasarkan hasil uji statistik deskriptif pada tabel 3 menunjukkan bahwa varibel dysfunctional audit behavior (Y) memiliki nilai minimum sebesar 23, nilai maksimum sebesar 43 dan. standar deviasi 5,441. Mean sebesar 33,61 menunjukkan rata-rata jawaban responden setuju dengan pernyataan kuesioner, hal ini berarti bahwa adanya kecenderungan responden dalam melakukan perilaku disfungsional dalam audit. Variabel sifat machiavellian $\left(\mathrm{X}_{1}\right)$ memiliki nilai minimum sebesar 14 
nilai maksimum sebesar 29, mean sebesar 23,07 dan standar deviasi sebesar 4,028. Hal ini menunjukkan bahwa sifat machiavellian yang dimiliki responden cenderung tinggi. Variabel time budget pressure $\left(\mathrm{X}_{2}\right)$ memiliki nilai minimum sebesar 17 nilai maksimum sebesar 32 dan mean sebesar 26,41 dan nilai standar deviasi 4,105. Hal ini menunjukkan bahwa time budget pressure akan membuat responden tertekan dalam pekerjaannya. Variabel LOC internal $\left(\mathrm{X}_{3 \mathrm{a}}\right)$ memiliki nilai minimum sebesar 17 nilai maksimum sebesar 33 dan mean sebesar 24,07, dan nilai standar deviasi 3,855. Hal ini menunjukkan bahwa responden memiliki LOC internal yang tinggi yang akan menurunkan kecenderungan penyimpangan perilaku dalam audit. Variabel LOC eksternal $\left(\mathrm{X}_{3 \mathrm{~b}}\right)$ memiliki nilai minimum sebesar 16 nilai maksimum sebesar 31 dan mean sebesar 24,65 dan nilai standar deviasi 3,640. Hal ini menunjukkan bahwa responden memiliki LOC internal yang tinggi.

Hasil analisis dinyatakan dalam bentuk persamaan regresi linear berganda pada Tabel 4 sebagai berikut.

Tabel 4.

Hasil Analisis Regresi Linear Berganda

\begin{tabular}{|c|c|c|c|c|c|}
\hline \multirow[t]{2}{*}{ Variabel } & \multicolumn{2}{|c|}{$\begin{array}{l}\text { Unstandardized } \\
\text { Coefficients }\end{array}$} & \multirow{2}{*}{$\begin{array}{c}\text { Standardized } \\
\text { Coefficients } \\
\text { Beta }\end{array}$} & \multirow[t]{2}{*}{$\mathbf{T}$} & \multirow[t]{2}{*}{ Sig. } \\
\hline & B & Std. Error & & & \\
\hline Constant & 29,291 & 3,707 & & 7,902 & 0,000 \\
\hline Sifat Machiavellian & 0,299 & 0,139 & 0,221 & 2,154 & 0,036 \\
\hline Time budget pressure & 0,330 & 0,125 & 0,249 & 2,638 & 0,011 \\
\hline LOC Internal & $-0,698$ & 0,84 & $-0,495$ & $-8,327$ & 0,000 \\
\hline LOC Ekstenal & 0,224 & 0,108 & 0,150 & 2,066 & 0,044 \\
\hline
\end{tabular}

Sumber:Data diolah, 2018

Berdasarkan Tabel 4 dapat disusun persamaan regresi linear berganda sebagai berikut. 
ISSN: 2302-8556

E-Jurnal Akuntansi Universitas Udayana

Vol.26.2.Februari (2019): 1161-1189

$Y=29,291+0,299 X_{1}+0,330 X_{2}-0,698 X_{3 a}+0,224 X_{3 b}+e$

Koefisien regresi sifat machiavellian $\left(\beta_{1}\right)$ memiliki tanda positif yang menunjukkan bahwa variabel sifat machiavellian mempunyai hubungan positif pada dysfunctional audit behavior. Dengan asumsi variabel lainnya konstan sementara sifat machiavellian $\left(\mathrm{X}_{1}\right)$ meningkat, maka dysfunctional audit behavior (Y) akan cenderung meningkat. Hasil ini menerima hipotesis pertama $\left(\mathrm{H}_{1}\right)$ yang menyatakan bahwa sifat machiavellian berpengaruh positif segnifikan pada dysfunctional audit behavior. Kondisi ini menggambarkan bahwa auditor dengan sifat machiavellian yang tinggi akan meningkatkan dysfunctional audit behavior atau penyimpangan perilaku dalam audit, sebaliknya apabila tingkat sifat machiavellian pada seorang auditor rendah maka dysfunctional audit behavior juga akan menurun.

Kondisi ini terjadi dimana auditor dengan sifat machiavellian yang tinggi akan cenderung melakukan manipulasi untuk mendapatkan tujuan yang diinginkan misalnya seperti reward. Sifat machiavellian merupakan sifat negatif karena mengabaikan pentingnya integritas dan kejujuran dalam mencapai tujuan. Kaitannya dengan teori atibusi, sifat machiavellian berpengaruh pada sifat kepribadian, persepsi diri, kemampuan dan motivasi. Auditor yang mempunyai sifat machiavellian memungkinkan untuk melakukan tindakan-tindakan yang melanggar etika profesi dalam hal manipulatif maupun mengabaikan integritas dan kejujuran dalam pencapain tujuannya. Hal ini menunjukkan semakin tinggi sifat machiavellian dalam diri seorang auditor, maka semakin tinggi juga tingkat penerimaan penyimpangan perilaku disfungsional dalam audit. Hasil ini sejalan dengan penelitian Purnamasari 
(2006), Saputri dan Wirama (2015), serta Winanda (2017) yang menyatakan bahwa sifat machiavellian berpengaruh positif pada dysfunctional audit behavior.

Koefisien regresi time budget pressure $\left(\beta_{2}\right)$ memiliki tanda positif yang menunjukkan bahwa variabel time budget pressure mempunyai hubungan positif pada dysfunctional audit behavior. Dengan asumsi variabel lainnya konstan sementara time budget pressure $\left(\mathrm{X}_{2}\right)$ meningkat, maka dysfunctional audit behavior (Y) akan cenderung meningkat. Hasil ini menerima hasil hipotesis kedua $\left(\mathrm{H}_{2}\right)$ yang menyatakan bahwa time budget pressure berpengarih positif pada dysfunctional audit behavior. Auditor yang mempunyai time budget pressure yang lebih tinggi akan menaikkan tingkat penerimaan penyimpangan perilaku dalam audit. Sebaliknya, auditor yang memiliki time budget pressure yang lebih rendah akan menurunkan tingkat penerimaan penyimpangan perilaku dalam audit.

Berdasarkan teori atribusi dapat dijelaskan bahwa time budget pressure berpengaruh pada dysfunctional audit behavior yang ditandai dengan adanya pembatasan anggaran waktu audit, akan membuat auditor tertekan sehingga hasil audit cenderung tidak optimal. Sedangkan hasil audit yang diharapkan harus sesuai dengan standar. Tekanan inilah yang membuat auditor melakukan perilaku penyimpangan untuk mencapai tujuannya. Hasil penelitian ini sejalan dengan penelitian Svanstrom (2016), Dewi (2015), serta Winanda (2017) yang menyatakan bahwa time budget pressure atau tekanan anggaran waktu berpengaruh positif pada penerimaan penyimpangan perilaku dalam audit. 
ISSN: 2302-8556

E-Jurnal Akuntansi Universitas Udayana

Vol.26.2.Februari (2019): 1161-1189

Koefisien regresi LOC internal $\left(\beta_{3 \mathrm{a}}\right)$ memiliki tanda negatif yang menunjukkan bahwa variabel LOC internal mempunyai hubungan negatif pada dysfunctional audit behavior. Dengan asumsi variabel lainnya konstan sementara LOC internal $\left(\mathrm{X}_{3 \mathrm{a}}\right)$ meningkat, maka dysfunctional audit behavior (Y) akan cenderung menurun. Hasil ini menerima hipotesis ketiga $\left(\mathrm{H}_{3 \mathrm{a}}\right)$ yang menyatakan bahwa locus of control internal berpengaruh negatif pada dysfunctional audit behavior.

Auditor yang memiliki locus of control internal yang tinggi cenderung percaya dengan hasil yang dicapai dari kemampuan dan usaha dalam diri auditor tersebut. Sehingga dalam pekerjaannya auditor tidak akan tergantung pada keberuntungan ataupun nasibnya, maka dari itu auditor dengan locus of control internal yang tinggi cenderung dapat mengahadapi situasi sulit dalam pekerjaannya tapa melakukan kecurangan yang dimana auditor akan meminimalisir terjadinya penerimaan penyimpangan perilaku dalam audit. Penelitian ini sejalan dengan (Donnelly et al. 2003) yang menyatakan bahwa locus of control internal akan menurunkan dysfunctional audit behavior. Penelitian Shapeero (2003) menyatakan locus of control internal akan berpengaruh negatif pada dysfunctional audit behavior. Sejalan dengan penelitian sebelumnya, penelitian Irawati (2005) menyatakan bahwa locus of control menurunkan dysfunctional audit behavior, atau dapat dikatakan berpengaruh negatif pada dysfunctional audit behavior.

Koefisien regresi LOC eksternal $\left(\beta_{3 b}\right)$ memiliki tanda positif yang menunjukkan bahwa variabel LOC eksternal mempunyai hubungan positif pada dysfunctional audit behavior. Dengan asumsi variabel lainnya konstan sementara 
LOC eksternal $\left(\mathrm{X}_{2 \mathrm{~b}}\right)$ meningkat, maka dysfunctional audit behavior (Y) akan cenderung meningkat. Hasil ini menerima hasil hipotesis kedua $\left(\mathrm{H}_{3 \mathrm{~b}}\right)$ yang menyatakan bahwa locus of control eksternal berpengaruh positif pada dysfunctional audit behavior. Semakin tinggi locus of control eksternal, maka semakin meningkat pula penerimaan penyimpangan perilaku dalam audit. Sebaliknya, semakin rendah locus of control eksternal maka semakin rendah pula penerimaan penyimpangan perilaku dalam audit.

Seseorang auditor yang mempunyai locus of control eksternal yang tinggi cenderung kurang maksimal dalam melakukan pekerjaannya, karena auditor tersebut akan bergantung pada keberuntungan, dan nasibnya yang membuat individu tersebut kurang percaya akan kemampuan dirinya. Berdasarkan teori atribusi suatu individu dapat bertindak menurut karakter personalitas mereka (Devi and Ramantha, 2017) Auditor yang memiliki locus of control eksternal yang tinggi akan cenderung mudah cemas dan berusaha melakukan tindakan apapun termasuk perilaku disfungsional untuk mengurangi kondisi tersebut ketika mereka mengalami tuntutan pekerjaan yang tinggi karena mereka meyakini hal yang mereka lakukan bukan semata-mata berasal dari dalam diri mereka melainkan dari faktor luar. Hasil penelitian ini sejalan dengan penelitian Donnelly et al. (2003), Kartika and Wijayanti (2007), Harini et al., (2010), serta Devi and Ramantha (2017) yang menyatakan bahwa locus of control eksternal berpengaruh positif pada dysfunctional audit behavior.

Hasil penelitian ini dapat membuktikan adanya pengaruh sifat machiavellian, time budget pressure, locus of control pada dysfunctional audit behavior akuntan 
ISSN: 2302-8556

publik di Bali. Hasil uji penelitian ini menyatakan bahwa sifat machiavellian berpengaruh positif pada dysfunctional audit behavior. Hal tersebut memiliki arti bahwa auditor yang memiliki sifat machiavellian yang tinggi, berpotensi tinggi pula untuk melakukan penyimpangan perilaku dalam audit atau yang disebut dengan dysfunctional audit behavior. Karena auditor yang memiliki sifat machiavellian yang tinggi akan cenderung mengabaikan integritas dan kejujuran serta melakukan apasaja untuk mencapai tujuannya. Penelitian ini mendukung teori atribusi yang menjelaskan tentang bagaimana kita menentukan penyebab perilaku seseorang, dalam hasil penelitian ini menyatakan bahwa sifat machiavellian yang tinggi yang menyebabkan semakin tinggi pula peluang auditor untuk menerima dysfunctional audit behavior. Penelitian ini juga mendukung teori motivasi dan pengharapan yang ditunjukkannya adanya motivasi dari auditor yang memiliki sifat machiavellian yang tinggi untuk mencapai tujuannya yang biasa dikaitkan dengan reward.

Hasil penelitian menunjukkan bahwa time budget pressure berpengaruh positif dan signifikan pada dysfunctional audit behavior, karena time budget pressure yang tinggi akan menjadikan auditor tertekan dan auditor cenderung melakukan apasaja tanpa terkecuali melakukan perilaku yang menyimpang. Penelitian ini mendukung teori atribusi yang ditunjukkannya dengan semakin tinggi time budget pressure, semakin tinggi pula peluang auditor untuk melakukan dysfunctional audit behavior. Penelitian ini juga mendukung teori motivasi dan pengharapan, auditor yang mengalami kondisi ini akan termotivasi untuk melakukan dysfunctional audit behavior. 
Hasil penelitian ini menyatakan bahwa locus of control internal berpengaruh negatif padadysfunctional audit behavior, karena seseorang idividu yang mempunyai locus of control internal yang tinggi percaya bahwa hasil yang diraih berasal dari kemampuan dan usahanya sendiri sehingga auditor yang mempunyai locus of control internal yang tinggi akan meminimalisir terjadinya dysfunctional audit behavior. Hasil penelitian ini mendukung teori atribusi, karena locus of control internal berpengaruh pada penurunan dysfunctional audit behavior. Penelitian ini tidak mendukung teori motivasi dan pengharapan, karena auditor yang memiliki locus of control internal yang tinggi tidak akan termotivasi untuk melakukan perilaku yang menyimpang dalam audit.

Penelitian ini menyatakan bahwa locus of control eksternal berpengaruh positif dan signifikan pada dysfunctional audit behavior, karena seseorang yang memiliki locus of control eksternal yang tinggi kurang percaya terhadap kemampuan dalam dirinya, melainkan lebih percaya terhadap nasib dan keberuntungan kondisi tersebut akan membuat seseorang untuk melakukan apasaja tidak terkecuali perilaku menyimpang dalam menyelesaikan pekerjaannya. Hasil penelitian ini mendukung teori atribusi, auditor dengan locus of control eksternal yang tinggi menjadi penyebab meningkatnya dysfunctional audit behavior. Penelitian ini mendukung teori motivasi dan pengharapan, karena auditor yang memiliki locus of control eksternal yang tinggi akan termotivasi untuk melakukan dysfunctional audit behavior.

Penelitian ini diharapkan memberikan implikasi bagi kantor akuntan publik sebagai pertimbangan dalam hal perekrutan auditor agar lebih selektif dalam 
ISSN: 2302-8556

E-Jurnal Akuntansi Universitas Udayana

Vol.26.2.Februari (2019): 1161-1189

merekrut calon auditor dengan mempertimbangkan karakter personal, dan juga membicarakan secara mendalam mengenai time budget pressure yang diberikan atasan kepada auditor dalam kantor akuntan publik untuk meminimalisir terjadinya dysfunctional audit behavior. Hasil penelitian ini menyatakan bahwa sifat machiavellian dan juga locus of control eksternal menjadi faktor penyebab terjadinya dysfunctional audit behavior pada auditor, yang dimana hal tersebut bagian dari karakteristik personal individu dan diharapkan KAP tidak mengabaikan karakteristik personal individu dalam perekrutan calon auditor.

Sedangkan hasil penelitian ini juga menunjukkan time budget pressure yang tinggi akan meningkatkan peluang auditor melakukan penyimpangan perilaku, yang dimana sebaiknya KAP membicarakan secara mendalam mengenai time budget pressure yang dianggarkan kepada auditor agar auditor tidak merasa tertekan yang dimana kondisi yang tertekan akan menyebabkan auditor untuk melakukan penyimpangan perilaku.

Penambahan jumlah variabel bebas pada model regresi akan meningkatkan atau menurunkan nilai error, oleh karena itu untuk mengetahui determinasi total pada model regresi linear berganda maka digunakan $\mathrm{R}$ square yang telah disesuaikan (adjusted) dengan nilai error. Hasil uji adjusted $\mathrm{R}^{2}$ disajikan pada tabel 5 sebagai berikut.

Tabel 5.

Hasil Koefisien Determinasi (Adjusted $\mathbf{R}^{2}$ )

\begin{tabular}{lcccc}
\hline Model & $\mathbf{R}$ & R Square & Adjusted $\mathbf{R}$ Square & Std. Error of the Estimate \\
\hline 1 & $0,939^{\mathrm{a}}$ & 0,882 & 0,872 & 1,944 \\
\hline Sumber: & Data diolah, 2018 & &
\end{tabular}


Berdasarkan tabel 5 dapat diketahui nilai dari adjusted $\mathrm{R}^{2}$ adalah 0,872 atau 87,2 persen. Artinya sebesar 87,2 persen variasi dysfunctional audit behavior dipengaruhi oleh model yang dibentuk oleh sifat machiavellian $\left(\mathrm{X}_{1}\right)$, time budget pressure $\left(\mathrm{X}_{2}\right)$, LOC internal $\left(\mathrm{X}_{3 \mathrm{a}}\right)$, LOC eksternal $\left(\mathrm{X}_{3 \mathrm{~b}}\right)$, sedangkan 12,8 persen dijelaskan oleh faktor lain yang tidak dijelaskan dalam penelitian ini.

Berdasarkan hasil pengolahan data, maka hasil uji kelayakan model dapat disajikan pada tabel 6 sebagai berikut.

Tabel 6.

Hasil Uji Kelayakan Model

\begin{tabular}{llccccc}
\hline & Model & Sum of Squares & Df & Mean Square & F & Sig. \\
\hline 1 & Regression & 1383,664 & 4 & 345,916 & 91,537 & $0,000^{\mathrm{a}}$ \\
& Residual Total & 185,169 & 49 & 3,779 & & \\
& 1568,833 & 53 & & & \\
\hline
\end{tabular}

Sumber:Data diolah, 2018

Berdasarkan tabel 6 hasil uji kelayakan model menunjukan bahwa signifikansi

F sebesar 0,000 lebih kecil dari 0,05, sehingga dapat disimpulkan bahwa model penelitian ini dikatakan layak untuk diteliti dan pembuktian hipotesis dapat dilanjutkan.

\section{SIMPULAN}

Sifat machiavellian berpengaruh positif dan signifikan pada dysfunctional audit bahavior. Hal ini mengindikasi bahwa individu dengan sifat machiavellian yang tinggi cenderung untuk melakukan perilaku disfungsional yang dikaitkan untuk mendapatkan reward. Auditor yang memiliki sifat machiavellian yang lebih tinggi akan melakukan segala cara demi mencapai tujuannya. 
ISSN: 2302-8556

E-Jurnal Akuntansi Universitas Udayana

Vol.26.2.Februari (2019): 1161-1189

Time budget pressure berpengaruh positif dan signifikan pada dysfunctional audit behavior. Hal ini diindikasikan karena auditor mengalami tekanan ketika terbatasnya anggaran waktu audit yang diterima oleh auditor tersebut sehingga auditor cenderung melakukan tindakan apapun termasuk melakukan perilaku disfungsional.

Locus of control internal berpengaruh negatif pada dysfunctional audit behavior. Hal ini disebabkan karena auditor yang memiliki locus of control internal yang tinggi meyakini kemampuan dan usaha dari diri mereka, tanpa bergantung pada keberuntungan, nasib, maupun lingkungan luar. Maka dari itu auditor dengan locus of control internal yang tinggi cenderung dapat mengahadapi situasi sulit dalam pekerjaannya tapa melakukan kecurangan yang dimana auditor akan meminimalisir terjadinya dysfunctional audit behavior.

Locus of control eksternal berpengaruh positif dan signifikan pada dysfunctional audit behavior. Hal ini terjadi karena individu yang mempunyai locus of control eksternal yang tinggi akan bergantung pada keberuntungan, dan nasibnya yang membuat individu tersebut kurang percaya akan kemampuan dirinya. Auditor yang memiliki locus of control eksternal yang tinggi akan berusaha melakukan tindakan apapun termasuk perilaku disfungsional untuk mengurangi kondisi sulit dalam pekerjaan karena mereka meyakini hal yang mereka lakukan bukan sematamata berasal dari dalam diri mereka melainkan dari faktor luar.

Diharapkan kepada pengelola Kantor Akuntan Publik, pembicaraan mengenai time budget pressure sangat penting untuk direncanakan dan diperhitungkan lebih 
A.A. Istri Pranyanita dan I Ketut Sujana. Pengaruh...

dalam lagi. Karena apabila auditor dituntut dengan anggaran waktu yang terbatas akan meningkatkan tekanan bagi auditor sehingga auditor cenderung melakukan tindakan apapun untuk menyelesaikan tugasnya.

Diharapkan kepada pengelola Kantor Akuntan Publik, lebih selektif dalam proses perekrutan dengan mempertimbangkan karakteristik personal meliputi sifat machiavellian, locus of control, maupun karakteristik lainnya dari calon auditor guna mencapai tujuan bersama dalam KAP tersebut.

Penelitian ini diharapkan mampu menjadi refrensi bagi peneliti selanjutnya yang tertarik melakukan penelitian mengenai dysfunctional audit behavior untuk dapat menggunakan ataupun menambahkan variabel lain seperti sikap skeptisme dan role stress untuk meningkatkan kualitas hasil penelitian. Perbedaan obyek penelitian, maupun lingkup wilayah penelitian, serta penambahan jumlah sampel juga bisa dilakukan agar penelitian yang dihasilkan dapat menyeluruh dan memberikan kontribusi untuk penelitian selanjutnya. 
ISSN: 2302-8556

E-Jurnal Akuntansi Universitas Udayana

Vol.26.2.Februari (2019): 1161-1189

\section{REFERENSI}

Bass, Bernard M. 1999. "Two Decades of Research and Development in Transformational Leadership." European Journal of Work and Organizational Psychology 8(1):9-32.

Basudewa, Dewa Gede Agung and Ni Ketut Lely Aryani Merkusiwati. 2015. "Pengaruh Locus Of Control, Komitmen Organisasi, Kinerja Auditor, Dan Turnover Intention Pada Perilaku Menyimpang Dalam Audit." E-Jurnal Akuntansi Universitas Udayana, Vol. 13.3 13(3).

Broberg, Pernilla, Torbjörn Tagesson, Daniela Argento, Niclas Gyllengahm, and Ola Mårtensson. 2017. "Explaining the Influence of Time Budget Pressure on Audit Quality in Sweden." Journal of Management and Governance 21(2):331-50.

Devi, Arista and Wayan Ramantha. 2017. "Tekanan Anggaran Waktu, Locus of Control, Sifat Machiavellian, Pelatihan Auditor Sebagai Anteseden Perilaku Disfungsional Auditor.” Akuntansi Universitas Udayana 18:2318-45.

Dewi, Ni Made. 2015. "Pengaruh Time Budget Pressure, LOC, Dan Task Complexity Pada Dusfunctional YSF Fungtional Audit Behavior Akuntan Publik. Ni Made Nia Riska Dewi ${ }^{1}$ Krisis Kepercayaan Akan Profesi Ini Semakin Terasa Saat Terjadinya Kasus Enron Pada Tahun 2002 Dimana Laporan .” 1:1-14.

DeZoort, F.Todd and Alan T. Lord. 1997. "A Review and Synthesis Of Pressure Effects Research in Accounting." Journal of Accounting Literature 16:28-85.

Domino, Madeline Ann. 2015. "Social Cognitive Theory: The Antecedents and Effects of Ethical Climate Fit on Organizational Attitudes of Corporate Accounting Professionals-A Reflection of Client Narcissism and Fraud Attitude Risk." Journal of Business Ethics 131(2):453-67.

Donnelly, David P., Jeffrey J. Quirin, and David O'Bryan. 2003. "Auditor Acceptance of Dysfunctional Audit Behavior: An Explanatory Model Using Auditors' Personal Characteristics." Behavioral Research in Accounting 15(1):87-110.

Donnelly, David P., Jeffrey J. Quirin, and David O’Bryan. 2011. “Attitudes Toward Dysfunctional Audit Behavior: The Effects Of Locus Of Control, Organizational Commitment, and Position." Journal of Applied Business Research (JABR) 19(1). 
Epstein, Barry Jay and Sridhar Ramamoorti. 2016. “Today's Fraud Risk Models Lack Personality Auditing with 'Dark Triad' Individuals In The Executive Ranks." The CPA Journal (March):15-21.

Gustati. 2012. "Persepsi Auditor Tentang Pengaruh Locus of Control Terhadap Penerimaan Perilaku Disfungsional Audit ( Survey Pada Auditor BPKP Perwakilan Provinsi Sumatera Barat )." Jurnal Akuntansi Manajemen 7(2):46-65.

Halman, Ridi. 2017. "Pengaruh Keterampilan (Skill), Atribut Personal, Pengetahuan (Knowledge), Dan Pengalaman Auditor Dalam Proses Pelaksanaan Audit Terhadap Kualitas Laporan Audit Yang Dihasilkan.” PROFITA 10(2):399404.

Harini, Dwi, Agus Wahyudin, and Indah Anisykurlillah. 2010. "Analisis Penerimaan Auditor Atas Dysfunctional Audit Behavior: Sebuah Pendekatan Karakteristik Personal Auditor." Simposium Nasional Akuntansi XIII Purwokerto 2010 91:399-404.

Husna, Febriana. 2012. “Analisis Pengaruh Karakteristik Personal Auditor Terhadap Penerimaan Auditor Atas Dysfunctional Audit Behaviour (Studi Empiris Pada Kantor Akuntan Publik Di Jawa Tengah Dan DI Yogyakarta)." Universitas Diponegoro 1-87.

Irawati, Yuke. 2005. "Hubungan Karakteristik Personal Auditor Terhadap Tingkat Penerimaan Penyimpangan Perilaku Dalam Audit." Simposium Nasional Akuntansi 8(September):929-40.

Kartika and Wijayanti. 2007. "Locus Of Control Sebagai Anteseden Hubungan Kinerja Pegawai Dan Penerimaan Perilaku Disfungsional Audit (Studi Pada Auditor Pemerintah Yang Bekerja Pada BPKP Di Jawa Tengah Dan DIY)." Simposium Nasional Akuntansi X Makassar UNHAS AUEP-05(26-28 Juli 2007):1-37.

Manullang, Asna. 2010. "Pengaruh Tekanan Anggaran Waktu Dan Resiko Kesalahan Terhadap Penurunan Kuialitas Audit ( The Influence of Time Budget Pressure and Risk of Error to Reduced Audit Quality )." Fokus Ekonomi 5(1):81-94.

Margheim, Loren, Tim Kelley, and Diane Pattison. 2005. “An Empirical Analysis of the Effects of Auditor Time Budget Pressure and Time Deadline Pressure." Journal of Applied Business Research 21(1):23-35. 
ISSN: 2302-8556

E-Jurnal Akuntansi Universitas Udayana

Vol.26.2.Februari (2019): 1161-1189

Paino, Halil, Zubaidah Ismail, and Malcolm Smith. 2010. "Dysfunctional Audit Behaviour: An Exploratory Study in Malaysia." Asian Review of Accounting 18(2):162-73.

Payne, Velma L. and Sylvia J. Hysong. 2016. "Model Depicting Aspects of Audit and Feedback That Impact Physicians' Acceptance of Clinical Performance Feedback." BMC Health Services Research 16(1):1-12.

Purnamasari, St.Vena. 2006. "Sifat Machiavellian Dan Pertimbangan Etis: Anteseden Indenpendensi Dan Perilaku Etis Auditor." Simposium Nasional Akuntansi 9 Padang 68(3):265-85.

Richmond, Kelly Ann. 2003. "Ethical Reasoning, Machiavellian Behavior, and Gender: The Impact on Accounting Students' Ethical Decision Making." Faculty of the Virginia Polytechnic Institute and State University 85-85 .

Ruric, Nida Desak Pradnya Paramitha. 2014. "Pengaruh Persaingan, Pemberian Jasa Lain, Dan Sifat Machiavellian Pada Independensi Auditor." E-Jurnal Akuntansi Universitas Udayana 7(3):778-90.

Saputri, I. G.Agung Yuli and Dewa Gede Wirama. 2015. "Tipe Kepribadian Pada Perilaku Disfungsional Auditor Akuntan Publik Justinus Aditya Sidharta Dalam Kasus Great River International Tahun 2003 . Bapepam Menemukan Telah Terjadi Rekayasa Laporan Keuangan Great.” 2:70-86.

Shapeero, M.Koh. H. 2003. Underrorting and Premature Sign-off in Public Accounting. Vol. 18.

Sososutikso, Christina. 2010. "Perilaku Disfungsional Akibat Tekanan Anggaran Waktu (Studi Empiris Di Lingkungan Badan Pengawas Daerah Tingkat I Dan Tingkat II Propinsi Maluku).” Jurnal Maksi 10(1):89-95.

Suprianto, Edy. 2009. "Pengaruh Time Budget Pressure Terhadap Perilaku Disfungsional Auditor.” JAI 5(1).

Svanstrom, Tobias. 2016. "Time Pressure, Training Activities and Dysfunctional Auditor Behavior: Evidence from Small Audit Firms." International Journal of Auditing 20.

Triki, Anis, Gail Lynn Cook, and Darlene Bay. 2017. "Machiavellianism, Moral Orientation, Social Desirability Response Bias, and Anti-Intellectualism: A Profile of Canadian Accountants." Journal of Business Ethics 144(3):623-35. 
A.A. Istri Pranyanita dan I Ketut Sujana. Pengaruh...

Vladu, Alina Beattrice and Dan Dacian Cuzdriorean. 2013. "Creative Accounting, Measurement and Behavior." Annales Universitatis Apulensis: Series Oeconomica 15(1):107-15.

Wahyudin, Agus, Indah Anisykurlillah, and Dwi Harini. 2011. "Analisis Dysfunctional Audit Behavior: Sebuah Pendekatan Karakteristik Personal Auditor." Jurnal Dinamika Akuntansi 3(2):67-76.

Winanda, Hendra. 2017. "Pengaruh Tekanan Anggaran Waktu, Sifat Machiavellian, Dan Kompleksitas Tugas Terhadap Perilaku Audit Disfungsional.” E-Jurnal Akuntansi Universitas Udayana 18(1):500-528. 